Thorax (1972), 27, 433.

\title{
Pores of Kohn
}

\author{
J. L. C O R D I N G LE Y \\ Department of Anatomy, King's College University of London, Strand, London, WC2R $2 L S$
}

\begin{abstract}
The history of the investigations into interalveolar communications (pores of Kohn) shows that the question whether they exist and, if so, their nature has for approximately a century been contentious. The present electron microscopic study of the lungs of mice demonstrates that alveolar pores are normal structures, with edges composed of intact alveolar wall. A number of planes are demonstrated from which a fully compatible reconstruction is made. It is concluded that pores are round or oval structures frequently having at least one type II alveolar cell forming part of their boundary.

It is further postulated that pores may be divided by a capillary column stretching across the space, resulting in two openings.

A type II alveolar cell forming part of the pore wall may straddle the capillary column. Alveolar macrophages may be found lying free in the pore or lying astride a capillary column. When lying in a corner position type II cells may occupy the full wall thickness and face into three alveoli.
\end{abstract}

Ever since Kohn (1893) described his findings in a patient who had died of acute fibrinous pneumonia there has been controversy about the nature of the interalveolar communications which he described and with which his name became associated the following year when his teacher, Hauser (1894), in presenting a further case, referred to these interalveolar openings as 'the pores of Kohn'. Were these alveolar pores histological artefacts or postmortem changes? Were they, if present in the living lung, formed in consequence of pathological conditions or were they present in the normal healthy lung? These are the questions which have intrigued numerous workers.

Kohn was not the first to observe alveolar pores. Communications between alveoli had been described as early as 1855 by Rainey and subsequently by Zenker (1862), Luschka (1863), and Roosevelt (1890), who observed bridges between adjacent alveoli in casts. Henle (1873) looked further at these openings and concluded that they were atrophic areas associated with emphysema whereas Delafield (1882), who also paid special attention to the matter, concluded that the openings were part of normal structure. Kohn and Hauser aroused renewed interest by their detailed descriptions of these interalveolar pores, especially as they disagreed on their origin, Kohn believing them to be pathological while Hauser regarded them as normal entities. It took another 45 years before it became generally agreed that the pores of Kohn were normal structures in mammalian lungs.

Ribbert (1894) and his team concluded that the pores were pathological and so, with reservations, did Virchow (1895). Hansemann (1895), in an extensive series using dyed gelatin, demonstrated from two to six pores per alveolus in normal lungs. Later, however, von Ebner (1899), in trying to repeat the experiment, claimed that Hansemann's pores were fixation artefacts. Hansemann (1900) returned to the fray by repeating his experiments on the lungs of man and other primates and confirmed his earlier findings and ascribed Ebner's failure to defects in his technique. He also noted that the pores were not particularly associated with elastic tissue. Schulze (1906) was one of the first to be converted from non-belief, and in his monograph on the comparative structure of lung established that pores were normal structures in all mammalian lungs but their frequency varied with the species. Merkel (1902) raised a new point by claiming that, although the pores were normal, they were not found in the newborn. Müller (1907) made the same point. Laguesse (1912) was another convert who stated that each alveolus had from one to seven pores in its wall and that they were 2 to $13 \mu \mathrm{m}$ in diameter. His pupil, Marchand (1912), in confirming these results in man and other mammals, also confirmed that their frequency varied with the species and also that they were absent at birth. He concluded that the pores in man 
developed at the end of the first year of life. A further observation was made by Oertel (1919) who, by a sophisticated wax reconstruction method using serial sections, found that not only did communications exist between alveoli of the same bronchi but also between alveoli of adjacent bronchi within a pulmonary segment. He also observed that their size and shape, being round or oval, varied with the degree of lung expansion.

Physiologists such as Adams and Livingstone (1931) provided further evidence of the existence of interalveolar communication as a result of a study of atelectasis resulting from obstructing bronchi at various levels. Van Allen, Lindskog, and Richter (1931), in studying the spread of various gases and vapours in the lung, similarly postulated that some form of interalveolar connexion must exist.

Pathologists such as Willis (1933) and Macklin (1935) accepted the evidence for the presence of pores and considered their importance as avenues for the spread of pathological processes such as infection. On the other hand, Loosli (1937) pointed out that textbooks of histology at that time had little or nothing to say regarding pores. Now, some 30 years later, the situation has not changed. An examination of 10 current textbooks of histology shows that four make no reference to the subject, one speaks of defects which may occur in the alveolar wall, three mention pores in passing, and finally only two comment further on their possible size or shape and number.

In the present investigation the alveolar walls of mice were examined with the electron microscope to confirm the presence of pores and to report their structure.

\section{MATERIALS AND METHODS}

Adult male T.O. Swiss mice of varying age were killed by the intravenous injection of Nembutal. The thorax was immediately opened, the trachea ligated and divided above, and the lungs and heart removed intact en bloc. Polythene tubing of a suitable bore was introduced into the trachea and ligated into position. The lung block was placed in a sealed chamber containing buffered isotonic saline at $4^{\circ} \mathrm{C}$ with the intratracheal tube exteriorized with its free end immersed in a container of buffered fixative at $4^{\circ} \mathrm{C}$. A negative pressure of $25 \mathrm{~cm} \mathrm{H}_{2} \mathrm{O}$ was induced in the chamber, resulting in the expansion of the lungs and at the same time filling the air passages with fixative precooled to $4^{\circ} \mathrm{C}$. The general technique has been described previously (Nicol and Cordingley, 1967).

The fixative employed was $4 \%$ glutaraldehyde in $0.67 \mathrm{M}$ cocodylate buffer. After one hour the lung was removed from the chamber and chopped into pieces suitable for electron microscopic examination and left for a further two hours in the above fixative at $4^{\circ} \mathrm{C}$. The tissue was washed overnight in cocodylate buffer and then post-fixed in Palade's osmium fixative for two hours, again all at $4^{\circ} \mathrm{C}$. Embedding took place in Araldite and sections were examined on an AEI EM6B. In a number of blocks a thick section ( $1 \mu \mathrm{m}$ thick) was cut immediately adjacent to the thin sections. The thick sections were examined by phase light microscopy and photographed so that direct comparison could be made between electron and light microscopic appearance.

\section{RESULTS}

Discontinuity was frequently observed in the alveolar wall. The free edges were found to be intact, thus dispelling the possibility of the discontinuities being tears in the wall produced during the preparation of the tissue. Type II alveolar cells were often found to be associated with the breaks in the alveolar wall. Quite often type II cells constituted the whole thickness of the alveolar wall and thus faced into two alveoli. On other occasions, type II cells were seen to have three faces where two of the faces were separated by what appeared to be a capillary column. In all, six main types of structural planes were observed. These are represented diagrammatically in Figure 1.

In plane 1 there is a gap bounded on two sides by free edges of typical alveolar wall lined by type I epithelial cells with a continuous basement membrane lying deep to the epithelial cell (Figs 2 and 3).

In plane 2 there are two sections of typical alveolar wall separated by a type II cell which is sitting like a plug, presenting two faces, one into each of two adjacent alveoli (Fig. 4).

In plane 3 there is a break in the alveolar wall. Areas were observed where the tenuous attachment of the alveolar wall to a type II cell, as seen in Figure 4, has become discontinuous, resulting in one edge being the same as in plane 1 and the other being capped by a type II cell.

Planes 4, 5, and 6 correspond to 1, 2, and 3 just described, with the addition of a relatively thin column composed essentially of a capillary surrounded in the case of plane 4 completely by type I epithelium (Fig. 5) and being positioned in the gap between the free edges of the wall. In plane 5 , the capillary column lies on the plugging type II cell, the type II cell forming a small portion of the epithelial lining of the column (Figs 6 and 7). Plane 6 may be divided into two subtypes, $6 \mathrm{a}$ and $6 \mathrm{~b}$ respectively, depending on whether the capillary column is applied to the type II cell found in the same position as described for plane 3 (Fig. 8) or 
Planes described.

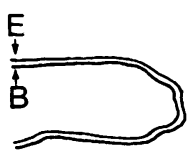

plane1.

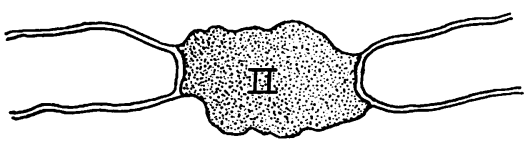
plane 2 .
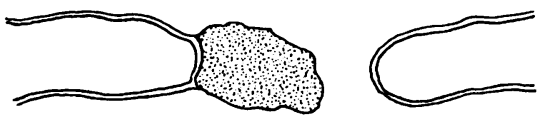

plane 3 .

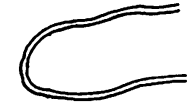

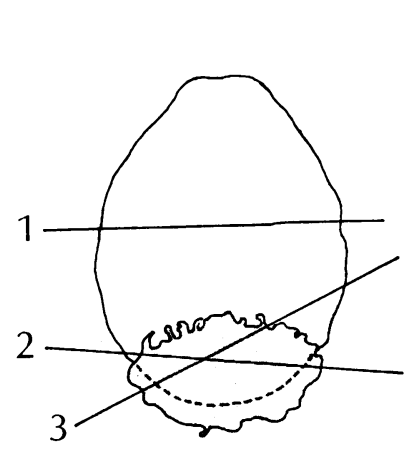
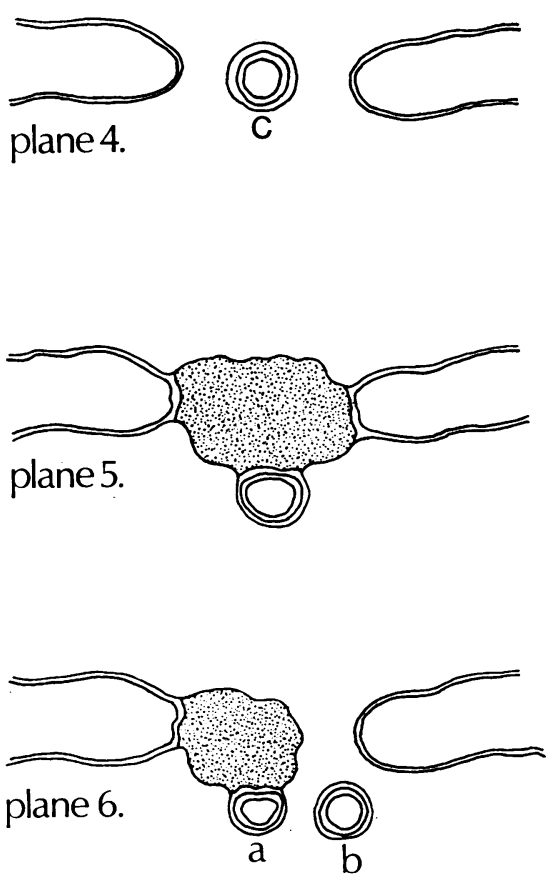

Reconstruction of pores.

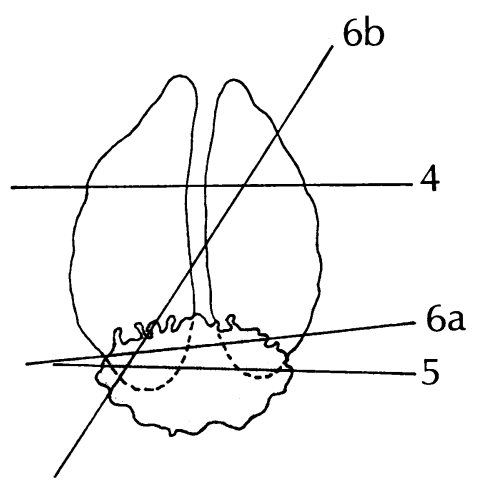

FIG. 1. 'Planes described' illustrate diagrammatically the various planes of gaps in the alveolar walls of mice found on electron microscopic examination: $E=$ alveolar wall epithelium (type 1$) ; B=$ basement membrane; $C=$ capillary column (capillary surrounded by basement membrane and epithelium); II (stippled) = type II alveolar cell.

'Reconstruction of pores' shows diagrammatically the postulated form of pores of Kohn based on the planes described. 


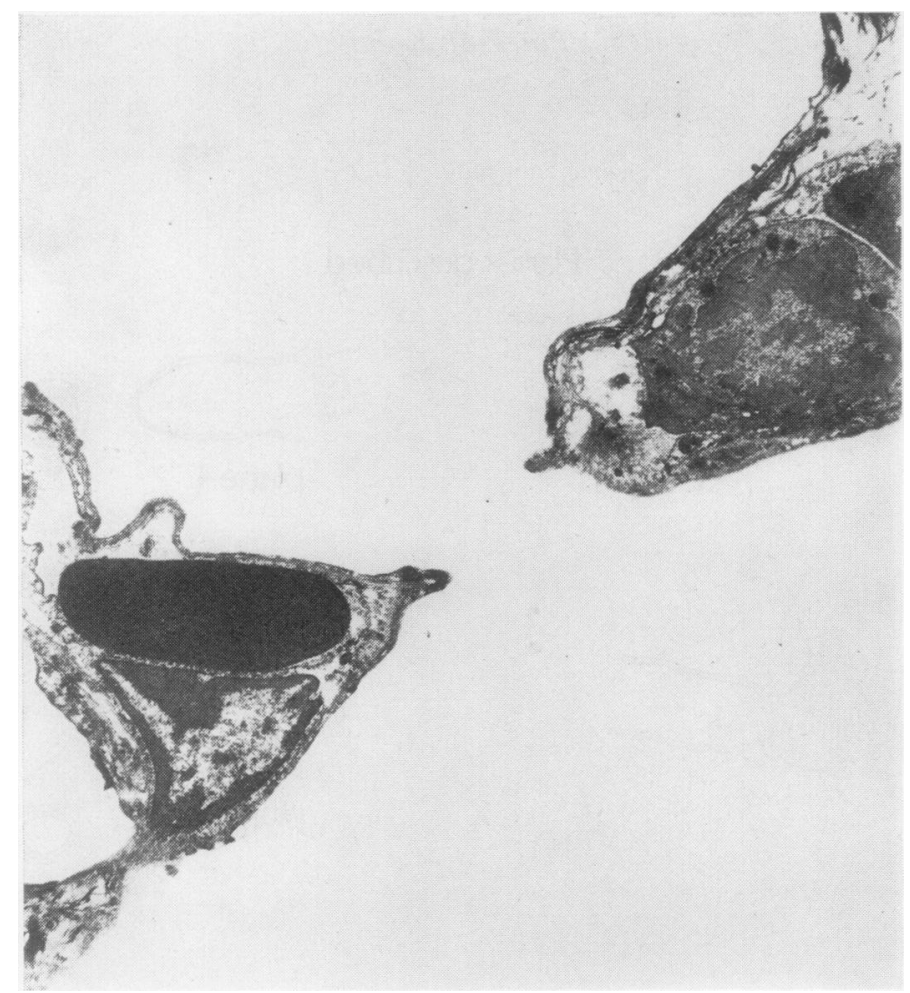

FIG. 2. Alveolar pore corresponding to plane $1(\times 6,650)$.

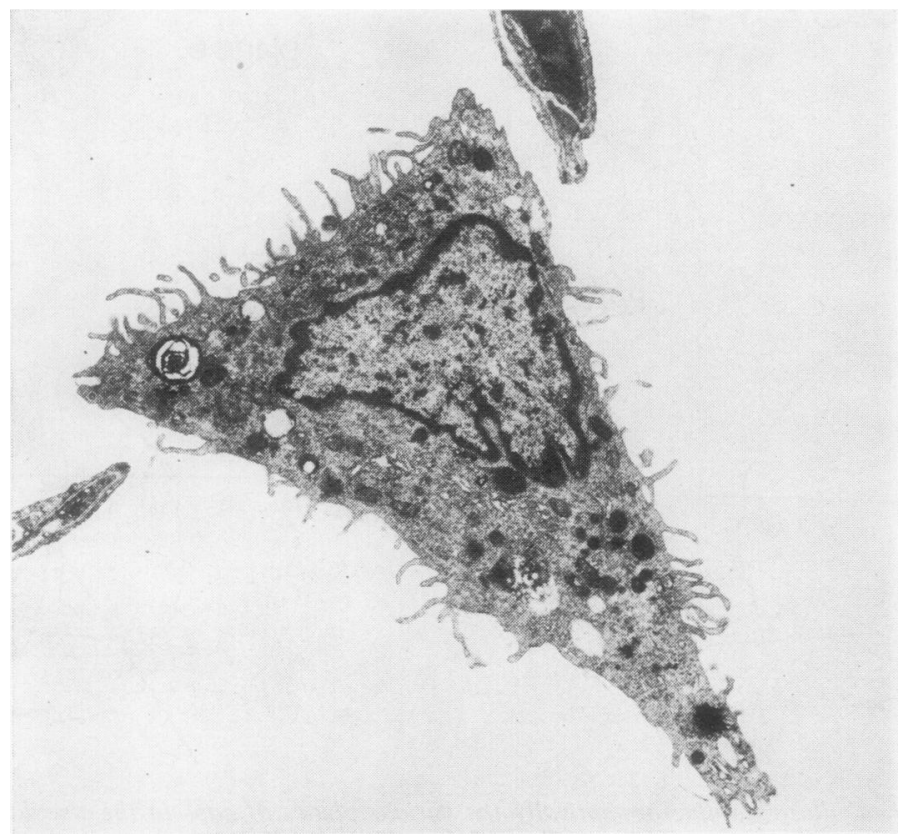

FIG. 3. Alveolar pore corresponding to plane 1 also showing alveolar macrophage lying free in the opening $(\times 6,650)$. 


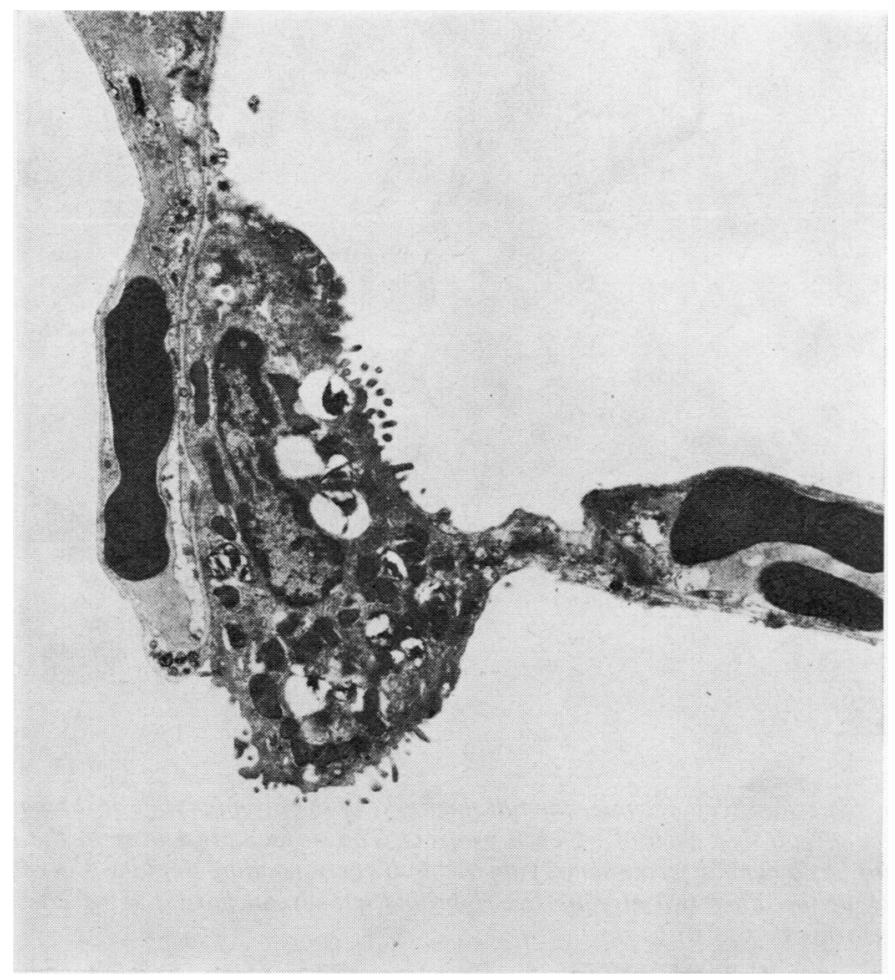

FIG. 4. A type II cell occupies the full thickness of the alveolar wall, thus projecting into two alveoli corresponding to plane $2(\times 6,650)$.

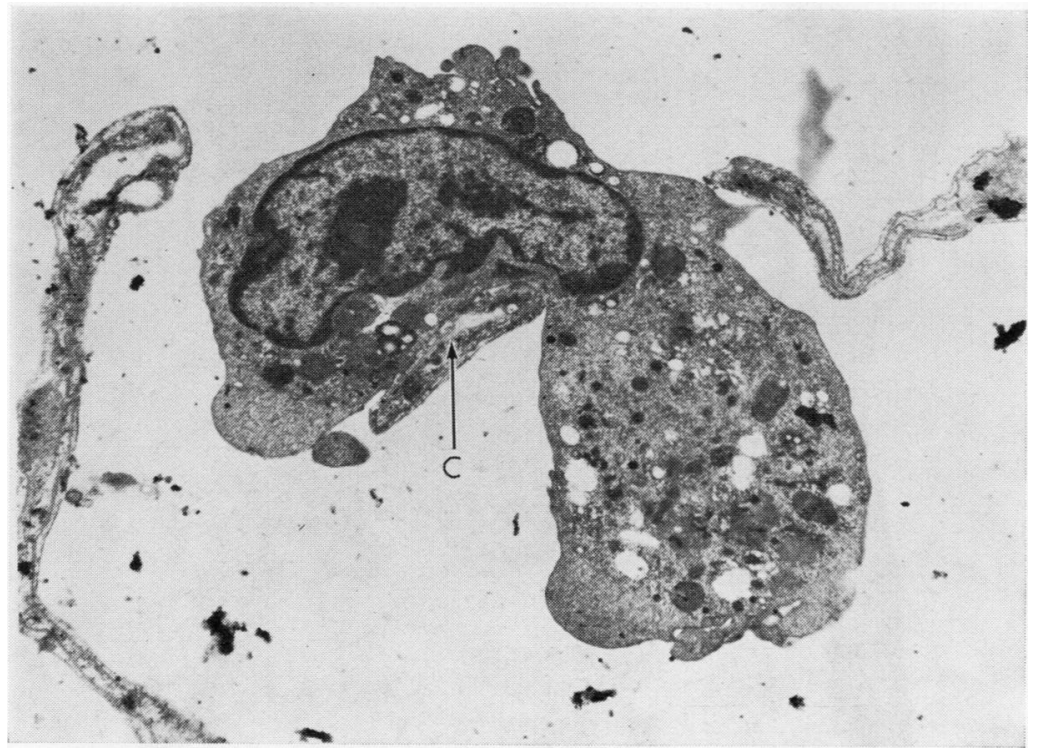

FIG. 5. Alveolar pore corresponding to plane 4. There is a central capillary column $(C)$, bending around which is an alveolar macrophage $(\times 10,000)$. 


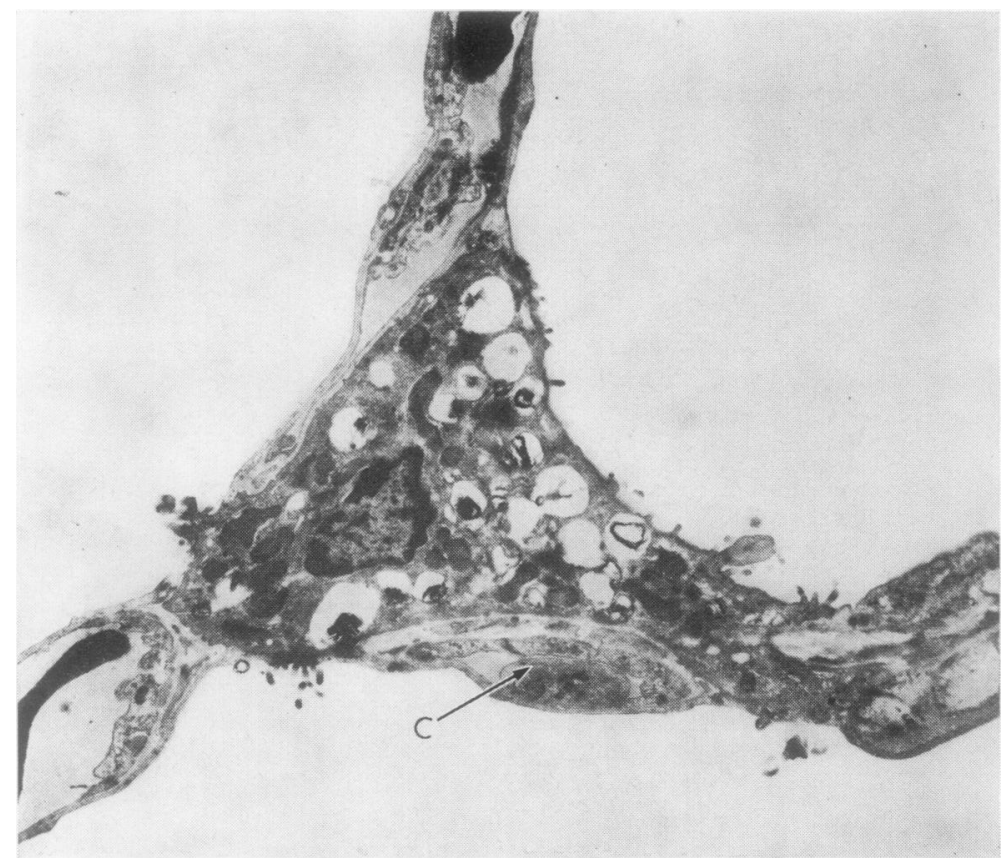

FIG. 6. A type II cell occupies the full thickness of the alveolar wall at the junction of three alveoli into each of which it projects. The surface presenting to the lower alveolus has a capillary column $(C)$ applied to it corresponding to plane 5 in relation to each of the other two alveoli. The right and left alveoli have a plane 2 relation to each other $(\times 6,650)$.

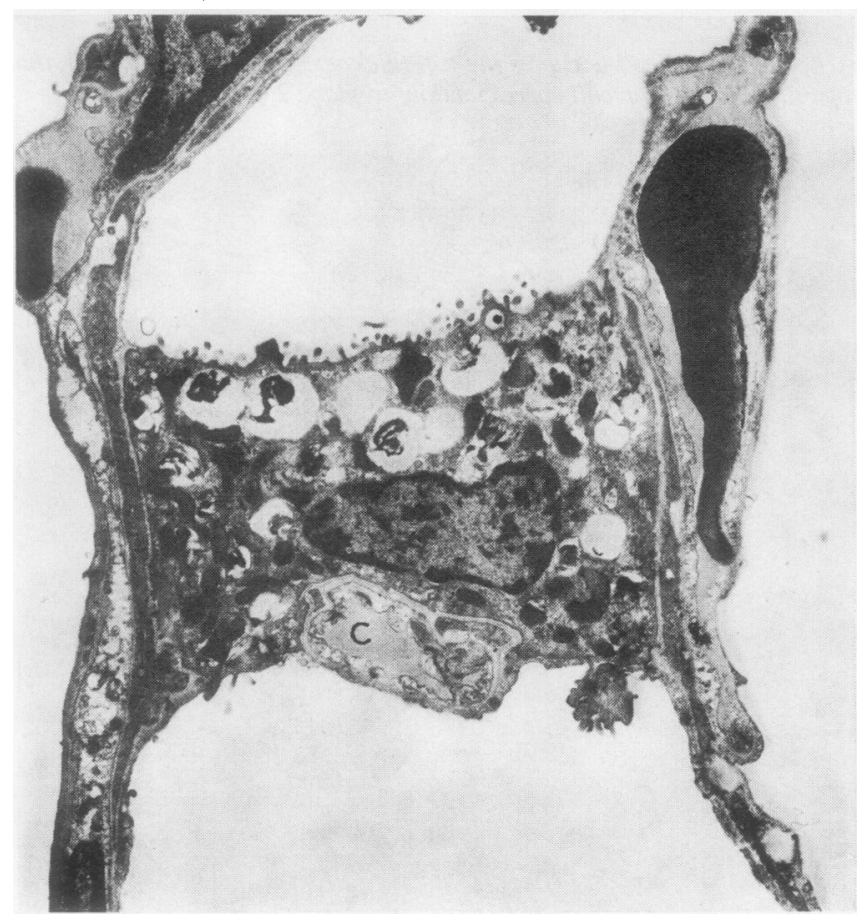

FIG. 7. A type II cell separating two alveoli with a capillary column (C) applied to the lower surface corresponding to plane $5(\times 6,650)$. 


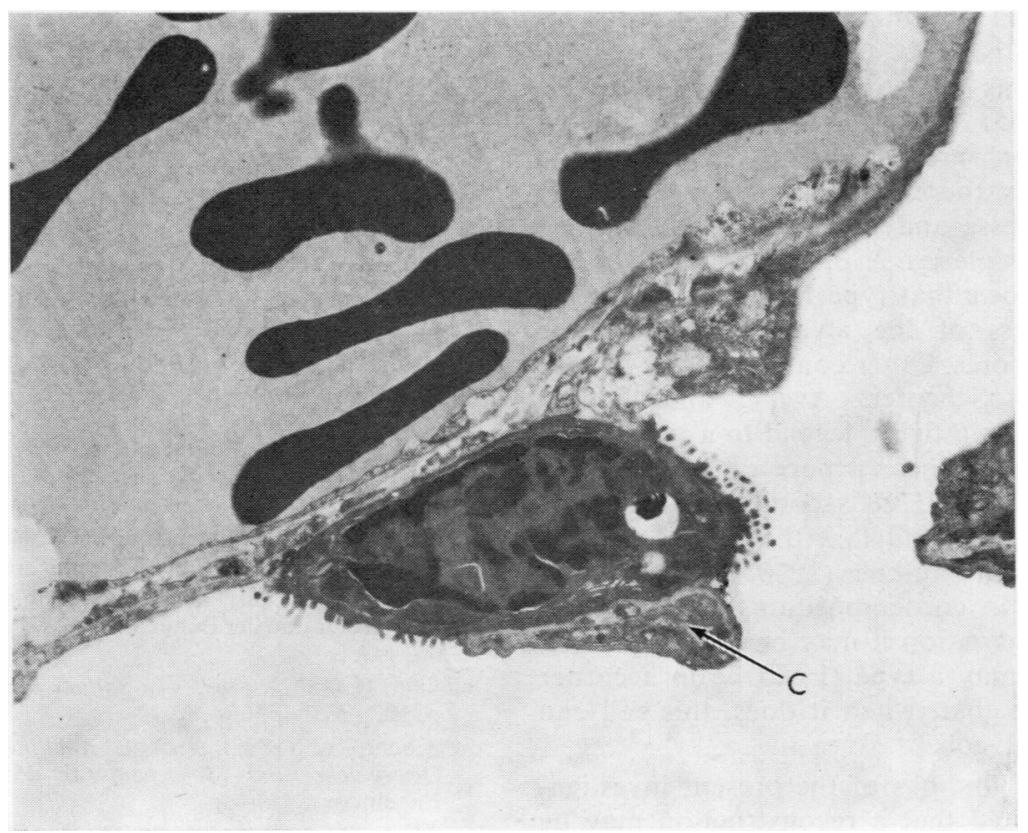

FIG. 8. Alveolar pore bordered by a type II cell, on one side, to which is applied a capillary column $(C)$ corresponding to plane $6 a(\times 6,650)$.

whether it lies, as it was also variously observed, on its own in the gap between the type II cell and the other free edge of the alveolar wall.

Macrophages were on several occasions found lying free in the alveolar pores, suggesting their passage from one alveolus to another (Figs 3 and 5). Figure 5 shows a macrophage lying astride a capillary column with part of the cell appearing to be endeavouring to pass through each half of a divided pore.

\section{DISCUSSION}

The nature of the alveolar wall lining was a contentious subject which was only finally resolved with the aid of the electron microscope (Low, 1953); hence it is little wonder that there should have been dissension regarding interalveolar pores. Yet for all that, electron microscopic study does not indicate any radically new concept regarding the pores of Kohn but rather confirms the opinion of the majority of light microscopists and clarifies some of the observations of others. It is quite clear that, in mice at all events, there are natural discontinuities in the alveolar wall of the healthy adult animal. The free edges are seen not to be tears since the basement membrane passes intact round from the alveolar wall facing into one alveolus to the wall facing the adjoining alveolus. Furthermore, the basement membrane is not denuded of epithelium.

Laguesse (1927) illustrated a section of lung showing not only three pores but also what he called an epithelial cell engaged in one of the pores presenting separate surfaces to two alveoli. The same observation was made again by Loosli (1937) when he noted the granular vacuolated cytoplasm of some cells he found lying in pores and which he considered to be epithelial. The following year he (Loosli, 1938) considered this cell in greater detail and identified it with what had been originally called the 'small nucleated epithelial cell', renamed by Lang (1925) the 'septal cell' (as he considered it to be of connective tissue origin). Loosli pointed out that this same cell was variously described by others as 'epicyte' (Clara, 1936), 'pneumocyte' (Businco, 1933), 'pericyte' (Bargmann, 1935), 'histiocyte' (Fried, 1934), and 'vacuolated macrophage' (Robertson and Uhley, 1936). Later again, Loosli, Adams, and Thornton (1949) emphasized the vacuolated nature of these cells scattered over the 
alveolar wall and at times sitting in pores. This vacuolated cell became the 'vacuolated macrophage' which was investigated and reviewed by Bertalanffy (1965) and subsequently the 'great alveolar cell' or, more currently, the type II alveolar cell. It is, therefore, seen that these observations of Laguesse and of Loosli are confirmed and reflected by planes $2,3,5$, and 6 described above, which shows that type II cells may occupy the full thickness of the alveolar wall and be associated with pores. Other confirmatory evidence is provided by Schaefer, Avery, and Bensch (1964) who refer in a figure legend to a type II cell 'in a typical location near a pore of Kohn'. They also noted that type II cells could make contact with adjacent alveoli and that they were often in a niche. Esterly and Faulkner (1970) note that these cells were often in corner positions. With respect to this latter observation it may be seen from Fig. 6 that not only may a type II cell lie in a corner position but also that, when it does, this cell can face into three alveoli.

In view of the findings of the present investigation it is postulated that a reconstruction may be made according to Figure 1 . It is suggested that pores occur in two forms, either as a simple opening or as a double opening having a relatively thin column formed of a central capillary clad in an epithelial-lined basement membrane separating the pore into two openings. The justification for regarding this arrangement as one pore divided into two rather than as two separate adjacent pores, lies in the interpretation of planes 5 and 6 . From this evidence it appears that one type II cell is common to both openings and therefore justifies the view that the paired openings consist of one pore divided by a capillary column which may cross a type II cell forming part of the edge of the pore. There is no reason to disagree with the observation of Oertel (1919) and others that the pores are round or oval in their general shape.

Laguesse (1927) made another relevant observation in reporting that pigmented alveolar phagocytes were found lying in pores apparently passing from one alveolus to another. This observation was confirmed and illustrated by Brodersen (1933), Macklin (1935), Loosli (1937, 1938), Loosli et al. (1949), and Schaefer et al. (1964). The finding of alveolar macrophages in pores is confirmed in Figures 3 and 5, and further comment by Loosli (1937) that macrophages were sometimes seen lying in two pores at the same time is illustrated in Figure 5, in which a macrophage is seen to by lying around a central capillary column with part of the cell in each half of a divided pore.
I wish to thank Miss M. McNeil for the technical assistance without which this paper would not have materialized. The electron microscope was financed by a grant from the Medical Research Council.

\section{REFERENCES}

Adams, W. E., and Livingstone, H. M. (1931). Obstructive pulmonary atelectasis. Arch. Surg., 23, 500.

Bargmann, W. (1935). Zur vergleichenden Histologie der Lungenalveole. Z. Zellforsch., 23, 335.

Bertalanffy, F. D. (1965). On the nomenclature of the cellular elements in respiratory tissue. Amer. Rev. resp. Dis., 91, 605.

Brodersen, J. (1933). Uber die Straub-, Körner-und Schaumzellen der Lunge und ihre Funktion. Z. mikr.-anat. Forsch., 32, 73.

Businco, A. (1933). La struttura del polmone alla luce della vecchie e nuove ricerche. Riv. sanit. sicil., 21, 1049.

Clara, M. (1936). Vergleichende Histobiologie des Nierenglomerulus und der Lungenalveole. Z. mikr.-anat. Forsch., 40, 147.

Delafield, F. (1882). Studies in Pathological Anatomy, Vol. 1, p. 102. Wood, New York.

von Ebner, V. (1899). In: A. Koelliker's Handbuch der Gewebelehre des Menschen, 6th ed., Vol. 3, p. 297. Engelmann, Leipzig.

Esterly, J. R., and Faulkner, C. S. (1970). The granular pneumocyte. Absence of phagocytic activity. Amer. Rev. resp. Dis., 101, 869.

Fried, B. M. (1934). The lungs and the macrophage system. Arch. Path., 17, 76.

Hansemann, D. (1895). Über die Poren der normalen Lungenalveolen. S.-B. Königl. preuss. Akad. Wiss., Berlin, 29, 999.

(1900). Ueber Victor von Ebner's Zweifel an der Existenz normaler Poren zwischen den Lungenalveolen. Arch. mikr. Anat., 55, 337.

Hauser, G. (1894). Ueber die Entstehung des fibrinösen Infiltrates bei der croupösen Pneumonie. Beitr. path. Anat., 15, 527.

Henle, J. (1873). Handbuch der systematischen Anatomie des Menschen, 2nd ed., Vol. 2, p. 278. F. Vieweg, Braunschweig.

Kohn, H. N. (1893). Zur Histologie der indurirenden fibrinösen Pneumonie. Münch. med. Wschr., 40, 42.

Lang, F. J. (1925). Über Gewebskulturen der Lunge. Arch. exp. Zellforsch., 2, 93.

Laguesse, E. (1912). Sur la structure des septa et des bourrelets septaux alvéolaires dans le poumon de l'homme. Bibliographie anatomique, 22, containing C.R. Ass. Anat. (14), 142.

(1927). Sur les pores interalvéolaires du poumon humain. Arch. Sci. méd., $51,45$.

Loosli, C. G. (1937). Interalveolar communications in normal and in pathologic mammalian lungs. Review of the literature. Arch. Path., 24, 743.

(1938). The structure of the respiratory portion of the mammalian lung with notes on the lining of the frog lung. Amer. J. Anat., 62, 375.

Adams, W. E., and Thornton, T. M. (1949). The histology of the dog's lung following experimental collapse. With special reference to the nature of the alveolar lining. Anat. Rec., 105, 697. 
Low, F. N. (1953). The pulmonary alveolar epithelium of laboratory mammals and man. Anat. Rec., 117, 241.

Luschka, H. (1863). Die Anatomie des Menschen, Vol. 1, pt. 2, p. 309. H. Laupp, Tübingen.

Macklin, C. C. (1935). Pulmonic alveolar vents. J. Anat. (Lond.), 69, 188.

Marchand, R. (1912). Les pores des alvéoles pulmonaires. Bibl. anat., 22, 57.

Merkel, F. (1902). Atmungsorgane. In: Handbuch der Anatomie des Menschen, edited by $\mathrm{K}$. von Bardeleben, Vol. 6, pt. 1: Atmungsorgane. Gustav Fischer, Jena.

Müller, J. (1907). Zur vergleichenden Histologie der Lungen unserer Haussäugetiere. Arch. mikr. Anat., 69, 1.

Nicol, T., and Cordingley, J. L. (1967). Reticuloendothelial excretion via the bronchial tree. In: Advances in Experimental Medicine and Biology, Vol. I, 'The Reticuloendothelial System and Atherosclerosis', edited by N. R. Di Luzio, and R. Paoletti, p. 58. Plenum Press, New York.

Oertel, L. (1919). Über die Alveolarporen in den Säugetierlungen. S.-B. Heidelberg. Akad. Wiss., math.-nat. Kl. Abt. B. Biol. Wiss., 12. Abhandlung.

Rainey, G. (1855). Critical examination of the evidence for and against the presence of epithelium in the air cells of the human lung. Brit. for. med.-chir. Rev., 16, 491.
Ribbert, H. (1894). Zur Anatomie der Lungenentzündungen. Fortschr. Med., 12, 371.

Robertson, O. H., and Uhley, C. G. (1936). Changes occurring in the macrophage system of the lungs in pneumococcus lobar pneumonia. J. clin. Invest., 15, 115.

Roosevelt, J. W. (1890). The anatomy of the thorax and lungs in relation to certain points in physical diagnosis. $M e d$. Rec. (N.Y.), 37, 201.

Schaefer, K. E., Avery, M. E., and Bensch, K. (1964). Time course of changes in surface tension and morphology of alveolar epithelial cells and $\mathrm{Co}_{2}$-induced hyaline membrane disease. J. clin. Invest., 43, 2080.

Schulze, F. E. (1906). Beiträge zur Anatomie der Säugetierlungen. S.-B. Königl. Preuss. Akad. Wiss. phys-math. Classe (Berlin), p. 225.

Van Allen, C. M., Lindskog, G. E., and Richter, H. G. (1931). Collateral respiration. Transfer of air collaterally between pulmonary lobules. J. clin. Invest., 10, 559.

Virchow, R. (1895). Klinische und anatomische Mittheilungen über indurative Lungenentzündung. Berl. klin. Wschr., 32, 129.

Willis, R. (1933). The Spread of Tumours in the Human Body, p. 241. Churchill, London.

Zenker, F. A. (1862). Beiträge zur normalen und pathologischen Anatomie der Lunge. Schönfeld, Dresden. 